\title{
Cloud technologies as a basis for the integration of teacher training systems for the International Baccalaureate schools
}

\author{
Vadim V. Grinshkun ${ }^{1}$, Lyubov A. Shunina ${ }^{2}$ \\ ${ }^{1}$ Peoples' Friendship University of Russia (RUDN University) \\ 6 Miklukho-Maklaya St, Moscow, 117198, Russian Federation \\ ${ }^{2}$ Moscow City University \\ 29 Sheremetyevskaya St, Moscow, 127521, Russian Federation
}

\begin{abstract}
Problem and goal. The article describes and substantiates the ways of solving the problem of the lack of approaches to the integration of methodical systems for training future teachers for International Baccalaureate programs based on the use of cloud technologies. The need for such integration is due to the fact that the training of teachers for International Baccalaureate schools involves professionals from various fields and organizations, including foreign speakers. The purpose of the described study was to confirm the effectiveness of the developed model of approaches to informatization of the system of training for future teachers of International Baccalaureate schools.

Methodology. A pilot study consisting of two stages was conducted. At the first stage, we worked with professors of the pedagogical university who are training future teachers for International Baccalaureate schools. The second stage was carried out based on the formation of two groups of students of the pedagogical university: control group (19 people) and experimental group (17 people). In the experimental group, students were trained in the conditions of integrated methodical systems of disciplines based on a specially developed model of approaches to informatization of training for future teachers of International Baccalaureate schools.

Results. The study found that the integration of methodical systems using cloud technology to organize joint work on training future teachers for International Baccalaureate schools contributes to the effectiveness of the formation of professional competence of such teachers.

Conclusion. The effectiveness of the developed model of approaches to the integration of methodical disciplines that form the basis for training future teachers for International Baccalaureate schools is experimentally proved.
\end{abstract}

Keywords: informatization of education, methodical system of training, integration, cloud technologies, model, teacher training, International Baccalaureate

Problem statement. The modern world is characterized by the desire of society to learn and develop throughout life. The current situation allows young people to carry out this process not only at home but also in other countries of the world.

(C) Grinshkun V.V., Shunina L.A., 2020

(c) (i) This work is licensed under a Creative Commons Attribution 4.0 International License https://creativecommons.org/licenses/by/4.0/ 
There is no doubt that the International Baccalaureate (IB) programs stand out among the educational systems that allow students to study at different levels in different countries without any difficulties in mastering the program. Graduates of International Baccalaureate schools usually have a good level of theoretical and practical training, are ready to solve non-standard problems and can offer atypical solutions in life situations. For the successful education of such graduates, pedagogical personnel with a certain set of competencies are required.

The study of approaches to teaching students and the work of teachers under the International Baccalaureate programs was covered in their works by M.Y. Shneyder, N.A. Usova, E.I. Nikonorova, K.E. Bezukladnikov, A.E. Pavlova, R. Brown, E.B. Hacking, O. Halic, P. Grace and others [1-11].

A developing and renewing system of education and science needs teachers who are ready for self-improvement, in both the subject area and mastering new modern techniques and technologies, including information. Information technologies are actively used not only in the educational process but also in the field of monitoring and measuring the outcomes of education, in the scientific, methodical and organizational activities of an educational institution. This topic is covered in the works of I.B. Gotskaya, S.A. Bazhenova, S.G. Grigoriev, O.Y. Zaslavskaya, A.Y. Kravtsova, I.V. Robert and other authors [12-16].

The specifics of the system of teacher training for International Baccalaureate schools are such that it involves a large number of different professors, including foreign ones. Such professors work in different departments of the university, in existing International Baccalaureate schools, are employers, scientists, practitioners, etc. In these conditions, it is difficult to implement their methodical, terminological, organizational and other relationships. First of all, this leads to inconsistency, unjustified duplication and even contradiction of the created and implemented methodical systems. In fact, different professors who are not fully connected with each other work with one particular student - a future teacher; he studies according to methodical systems that are not completely connected with each other.

Through the use of information technology, the possibilities for building an individual learning path, organizing cognitive activities, and forming new approaches to teaching and learning have expanded significantly. Many of the approaches are based on the use of cloud technologies, which have proven to be a convenient, affordable and reliable tool for organizing the educational process. It has been suggested that cloud technologies have integration potential and can be successfully used in organizing interaction between professors, while the organization of such collaboration can significantly expand and strengthen inter-subject and meta-subject communications, contributing to the integration of methodical systems, and positively affect the formation and consolidation of a wide range of competencies and skills among teachers who implement the International Baccalaureate programs.

Method of research. In the course of the study, we analyzed the master's program "International Baccalaureate: Theory and Technology" for the training of teachers for the International Baccalaureate schools, implemented at Moscow City University. This made it possible to identify some substantial fragmentation of the academic disciplines, the information resources involved, and educational tech- 
nologies, as well as a weak relationship (or complete lack of relationship) between some substantial blocks. This can lead to the impossibility of students applying their existing knowledge and skills in the new conditions, as well as to the formation of an incomplete idea of the subject being studied and a causal relationship of events and processes that will accompany their future professional activities.

In the course of the study, we developed a model of collaboration between professors of Moscow City University and other organizations involved in the training of teachers for the International Baccalaureate schools that is based on the use of cloud technologies (Figure 1).

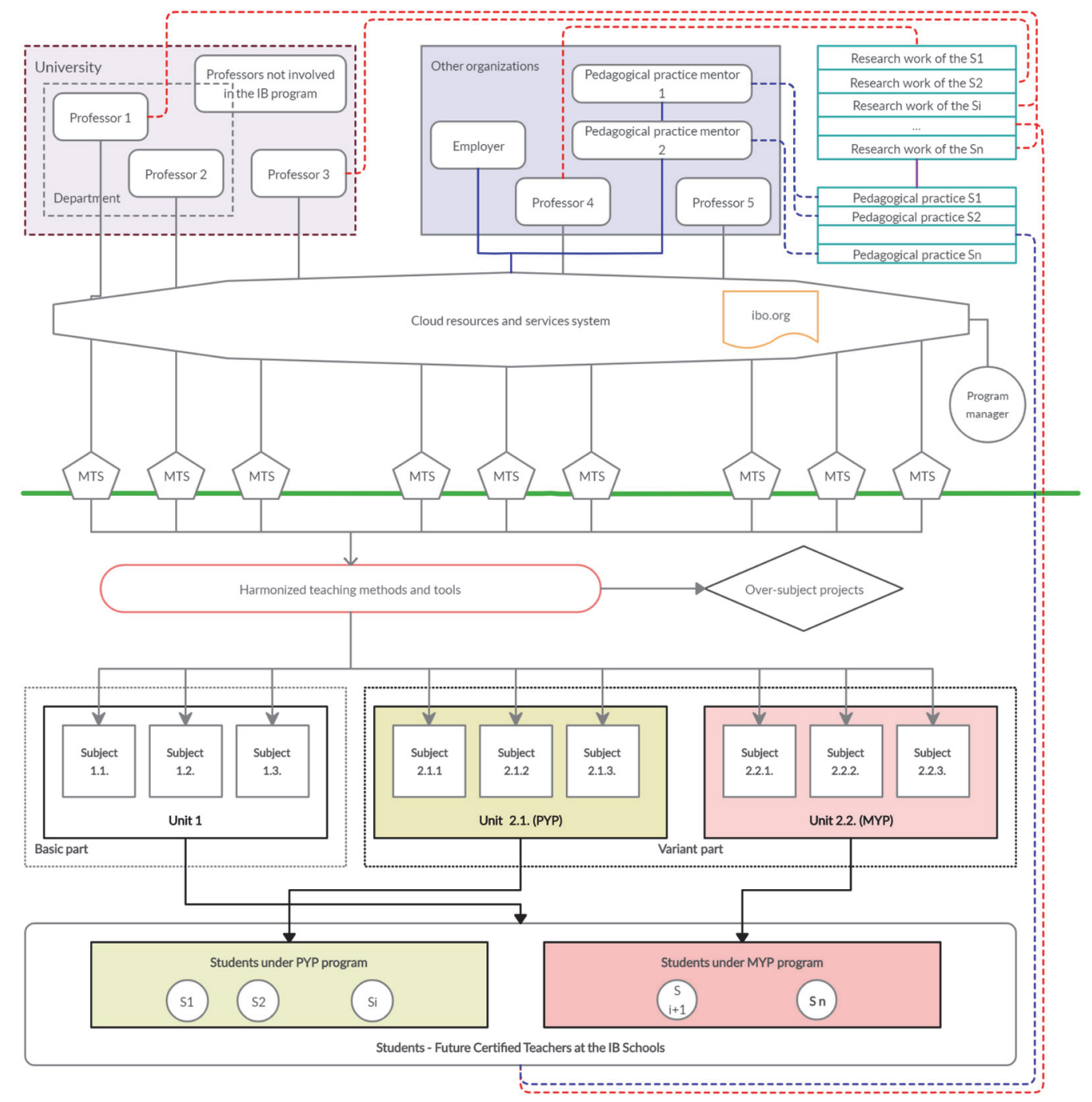

Figure 1. A model based on the use of cloud resources and services demonstrating the collaboration between professors who train teachers for the International Baccalaureate schools

This model is based on the necessity to use cloud technologies which will eliminate the disadvantages described above. Using a system of cloud resources and services is a fundamental element for organizing work on the integration of methodical systems and provides a solution to several important tasks. 
1. Organization of a stable and convenient communication between all the participants of the educational process. That was previously impossible due to the lack of integration into a single "physical" structural unit.

2. Storage and remote access to documents necessary for the organization of the educational process. The possibility to organize joint work with them for professors, including access to the resources of the library of methodical and normative materials of the International Baccalaureate through the portal www.ibo.org

3. Joint planning of events, timely informing, expanding the possibility of their integration into the educational process, which will qualitatively expand the content and forms of educational activity.

4. Expanding the tools for the head of the educational program for the organization of interaction and informal communication with the teaching stuff.

Also, due to the organization of interaction between participants of the educational process, the quality and role of pedagogical practice and the interaction process in the framework of the research work of the student have changed, in which practice mentors, academic advisers and employers are now more involved.

Figure 2 demonstrates a general system of cloud resources and services selected and structured during the study, which became the basis for the model of integrating the work of professors and the formation of methodical systems.

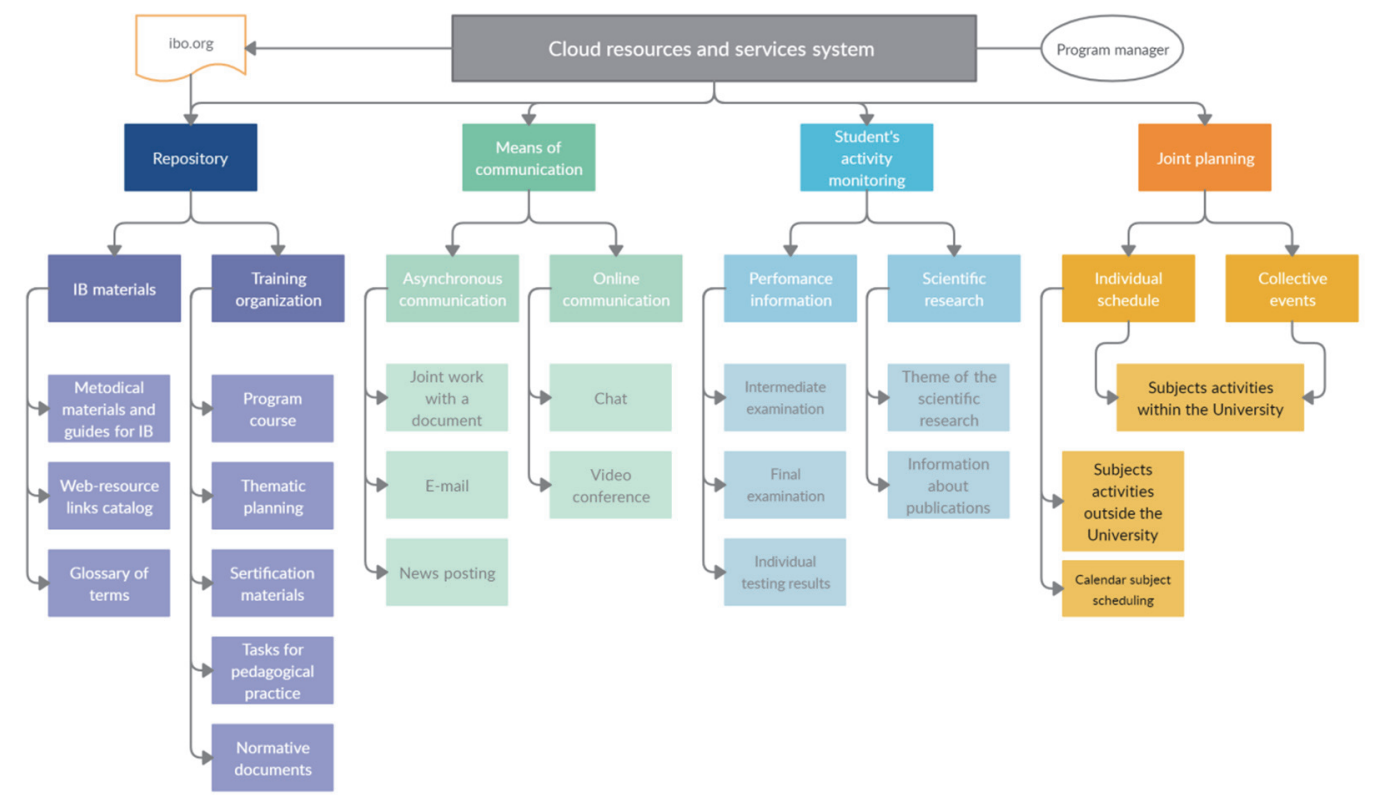

Figure 2. Systematization of cloud resources and services, providing integration of methodical systems

Among the recommended cloud resources and services are Dropbox, Evernote, Miro, Telegram, Microsoft Office Teams, Teamup and others. The cloud technology toolkit expands the possibilities of interaction between professors for the integration of methodical systems not sequentially and once, but repeatedly and in those combinations that are relevant at a particular moment, for specific professors and groups of students, in accordance with specific goals and objectives. This allows 
to organize over-subject group or personal projects that play a special role in the formation of the professional competence of teachers of the International Baccalaureate schools.

In order to evaluate the effectiveness of the recommended approaches, developed models and selected cloud resources, a pedagogical experiment was organized during the study. The research base is the department of informatization of education of the institute of digital education of Moscow City University. The experimental verification is divided into two stages, the purpose of each is a sequential search for answers to two previously formulated questions.

Stage 1. Does the joint work of professors using cloud technologies contribute to integrate methodical systems in the training of future teachers for the International Baccalaureate schools?

Stage 2. Does the integration of methodical systems increase the efficiency of the formation of professional competence of teachers for the International Baccalaureate schools?

For the implementation of the first stage of the experiment, we selected three subjects that are taught in the first semester of the first year of the above-mentioned master's program. Professors who teach these subjects took part in the preliminary survey, the purpose of which was to determine the initial idea of the respondents in three areas:

- knowledge of the basic provisions of the IB system;

- knowledge of the capabilities of cloud technologies and the degree of their use in their work;

- understanding of the necessity and possibility of integrating methodical systems in the training of future teachers for the International Baccalaureate schools.

Further work with professors during the semester was based on the results and materials obtained during the study. Each of them was offered a set of selected cloud resources and services, as well as guidelines for its use in order to ensure the integration of methodical training systems in three subjects. In particular, they were asked to record in a free form the degree of use of the offered services in their joint work.

To implement the second stage of the experiment, three subjects taught in the second semester of the first year were selected, an experimental (19 people) and a control (17 people) group of students studying in the master's degree program were formed. The professors teaching the selected disciplines were offered an updated set of cloud resources and services, guidelines for its use, and a diary of reflection.

Results and discussion. During the first stage of the experiment, a second survey was held at the end of the semester, to reveal the opinion of professors on the same categories of questions as at the beginning of the academic year. The comparative results of the preliminary and final surveys are shown in Figure 3.

The analysis of the results allows to state an increase in indicators in two of the three declared areas of the survey.

The results of the first stage of the experimental verification prove that the joint work of professors using cloud technologies contributes to the integration of methodical systems in the training of future teachers for the International Baccalaureate schools. This conclusion indicates the validity and feasibility of the transition to the second stage of the experimental verification. 

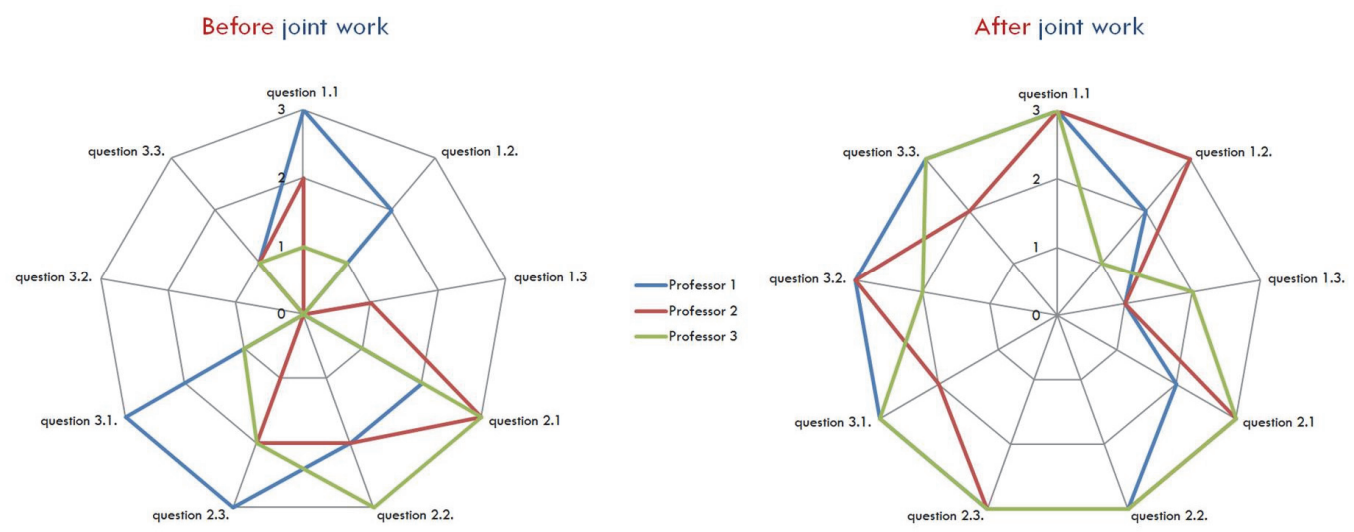

Figure 3. Results of surveys of professors who train teachers for the International Baccalaureate schools

At the second stage of the experimental verification, to evaluate the impact of the integration of methodical systems on increasing the effectiveness of the formation of professional competence of teachers for the International Baccalaureate schools, the results of students from the experimental and control groups were analyzed. These results were obtained during the control examination of knowledge in the selected subjects. A diagram that shows in comparison the value of the average score for each of the subjects for the control and experimental groups of students was constructed based on the obtained data (Figure 4).

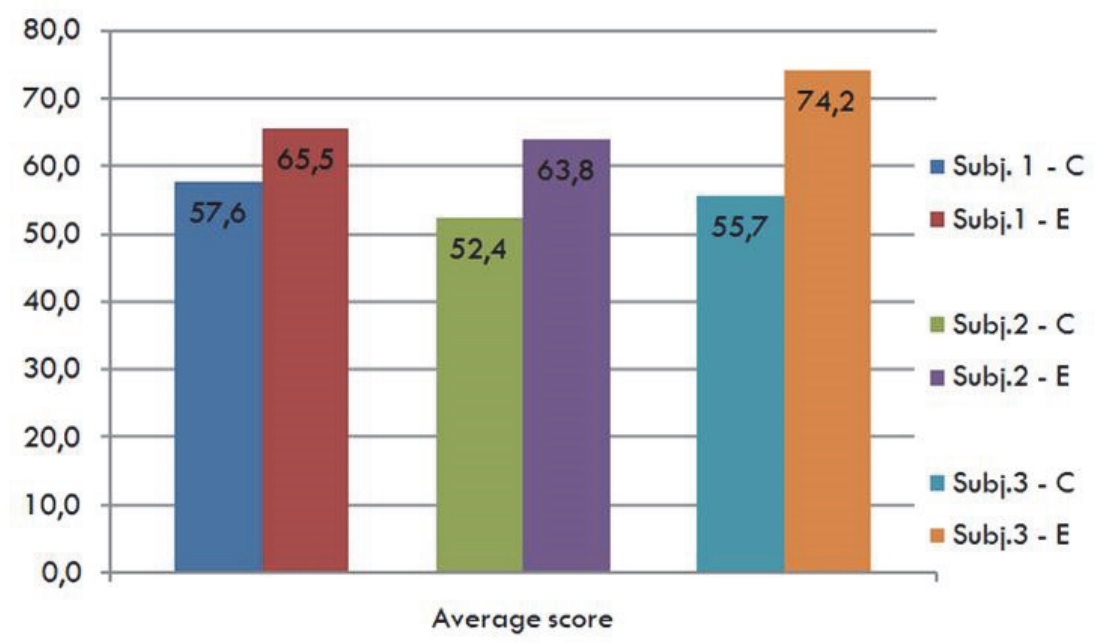

Figure 4. Performance of students of the experimental and control groups in the selected subjects based on the results of the control examination

As the results of the control group, we used archival data of a qualitative evaluation of the formation of professional competence of students, provided by the program course of each subject. This fact makes it impossible to determine the initial index of professional competence development for the control group. Nevertheless, we can state a clear increase in the average score for the experimental group, compared with the control group for the same period. 
Conclusion. This research allows us to state that the developed model of approaches to the integration of methodical training systems for future teachers, as well as the selected and configured cloud resources and services, which are the basis of the model, lead to an increase in the effectiveness of the formation of professional competence of a teacher planning his pedagogical activities in schools working under programs of the International Baccalaureate.

\section{References}

[1] Bezukladnikov KE, Kruze BA. Lingvodidakticheskie osnovy podgotovki uchitelya Mezhdunarodnogo bakalavriata: lingvoinformacionnyj i kompetentnostnyj podxody [Linguo-didactic fundamentals of teacher training for the International Baccalaureate: linguo-informational and competency-based approaches]. PNRPU Linguistics and Pedagogy Bulletin. 2013;7(49):42-50.

[2] Nikonorova EI. Primenenie innovacionnyx resursov dlya individualizacii obucheniya $\mathrm{v}$ sisteme "Mezhdunarodnyj bakalavriat" v usloviyax informatizacii obrazovaniya [The use of innovative resources to individualize education in the "International Baccalaureate" system in the context of informatization of education]. Informatization of continuing education - 2018 (ICE-2018): proceedings of the international scientific conference (vol. 1, pp. 639-645). Moscow: RUDN University Publ.; 2018.

[3] Pavlova AE. Razvitie kommunikativnoj kompetencii koordinatorov programm "Mezhdunarodnogo bakalavriata" s ispolzovaniem sredstv informatizacii obrazovaniya [The development of the communicative competence of the coordinators of the programs of the "International Baccalaureate" using tools for informatization of education]. Vestnik Moskovskogo gorodskogo pedagogicheskogo universiteta. Seriya: Informatika i informatizacija obrazovanija [Bulletin of the Moscow City Pedagogical University. Series: Informatics and Informatization of Education]. 2019;4(50):59-63.

[4] Brown R. Mathematical Modelling in the International Baccalaureate, Teacher Beliefs and Technology Usage. Teaching Mathematics and its Applications: An International Journal of IMA. 2002;21(2):67.

[5] Christodoulou A, Duncan J, Nelmes G. What is the effect of choice on students' motivation and performance? IB Journal of Teaching Practice. 2012;1(1):1-15.

[6] International Baccalaureate Organization. Fostering interdisciplinary teaching and learning in the MYP. IB Publishing Ltd.; 2009.

[7] Grace P. Individuals \& Societies (MYP by concept 3). Hodder Education; 2017.

[8] Grinshkun V, Usova N. Use of the Hardware and Software Complex "Moscow Electronic School" in Training Teachers Working Under the International Baccalaureate Programmes. Journal of Siberian Federal University. Humanities \& Social Sciences. 2019;9(12):1622-1634.

[9] Hacking EB, Blackmore C, Bullock K, Bunnell T, Donnelly M, Martin S. International Mindedness in Practice: The Evidence from International Baccalaureate Schools. Journal of Research in International Education. 2018;17(1):3-16.

[10] Halic O, Bergeron L, Kuvaeva A, Smith A. The International Baccalaureate's Bilingual Diploma: Global Trends, Pathways, and Predictors of Attainment. International Journal of Educational Research. 2015;69:59-70.

[11] Ryan AM, Heineke AJ, Steindam CE. Preparing Globally Minded Teachers Through the Incorporation of the International Baccalaureate. The Journal of Education. 2014;194(3):39-51.

[12] Bazhenova SA, Shunina LA. Vozmozhnosti onlajn-servisov dlya vizualizacii uchebnoj informacii [The possibilities of online services for the visualization of educational information]. Informatization of continuing education - 2018 (ICE-2018): proceedings of the international scientific conference (vol. 1, pp. 413-416). Moscow: RUDN University Publ.; 2018.

[13] Gotskaya IB, Zhuchkov VM. Aktualizaciya soderzhaniya obucheniya cifrovym proizvodstvennym texnologiyam bakalavrov i magistrov texnologicheskogo obrazovaniya: postanovka problemy [Actualization of the content of training in digital manufacturing 
technologies for bachelors and masters in technological education: problem statement]. Informatization of continuing education - 2018 (ICE-2018): proceedings of the international scientific conference (vol. 1, pp. 132-137). Moscow: RUDN University Publ.; 2018.

[14] Zaslavskaya OYu. Kompetencii uchitelya v oblasti ispolzovaniya informacionnyx i telekommunikacionnyx texnologij $\mathrm{v}$ epoxu cifrovoj ekonomiki [Teacher competencies in the use of information and telecommunication technologies in the era of the digital economy]. Informatization of continuing education - 2018 (ICE-2018): proceedings of the international scientific conference (vol. 1, pp. 311-317). Moscow: RUDN University Publ.; 2018.

[15] Kravczova AYu. Sovershenstvovanie sistemy podgotovki budushhix uchitelej v oblasti informacionnyx i kommunikacionnyx texnologij $\mathrm{v}$ usloviyax modernizacii obrazovaniya [Development of the system of training future teachers in the field of information and communication technologies in the context of modernization of education]. Dissertation of the Doctor of Pedagogical Sciences. Moscow; 2004.

[16] Robert IV. O ponyatijnom apparate informatizacii obrazovaniya [About the conceptual apparatus of informatization of education]. Informatika $i$ obrazovanie [Informatics and Education]. 2002;(12):2-6.

\title{
Article history:
}

Received: 10 March 2020

Accepted: 13 April 2020

\section{For citation:}

Grinshkun VV, Shunina LA. Cloud technologies as a basis for the integration of teacher training systems for the International Baccalaureate schools. RUDN Journal of Informatization in Education. 2020;17(3):210-219. http://dx.doi.org/10.22363/2312-8631-2020-17-3-210-219

\section{Bio notes:}

Vadim V. Grinshkun, corresponding member of Russian Academy of Education, doctor of pedagogical sciences, full professor, professor of the department of information technologies in continuous education of the Peoples' Friendship University of Russia (RUDN University). E-mail: vadim@grinshkun.ru

Lyubov A. Shunina, senior lecturer of the department of informatization of education of the Moscow City University. E-mail: shunina.mgpu@gmail.com

\section{Облачные технологии как основа для интеграции систем подготовки учителей для школ Международного бакалавриата}

\author{
В.В. Гриншкун ${ }^{1}$, Л.А. Шунина ${ }^{2}$ \\ ${ }^{1}$ Российский университет дружбы народов \\ Российская Федеращия, 117198, Москва, ул. Миклухо-Маклая, 6 \\ ${ }^{2}$ Московский городской педагогический университет \\ Российская Федерация, 127521, Москва, ул. Шереметьевская, 29
}

Аннотация. Проблема и иеель. В статье описываются и обосновываются пути решения проблемы отсутствия подходов к интеграции методических систем подготовки будущих учителей для работы по программам Международного бакалавриата, основан- 
ной на применении облачных технологий. Необходимость такой интеграции обусловлена тем, что в подготовке учителей для школ Международного бакалавриата задействованы профессионалы из различных сфер и организаций, в том числе зарубежные педагоги. Целью описываемого исследования являлось практическое подтверждение эффективности разработанной модели подходов к информатизации системы обучения будущих учителей для школ Международного бакалавриата.

Методология. Выполнено опытно-экспериментальное исследование, состоящее из двух этапов. На первом этапе проводилась работа с преподавателями педагогического вуза, подготавливающими будущих учителей для школ Международного бакалавриата. Второй этап осуществлялся на основе формирования контрольной (19 чел.) и экспериментальной (17 чел.) групп студентов педагогического вуза. В экспериментальной группе студенты - будущие учителя обучались в условиях интегрированных методических систем дисциплин на основании специально разработанной модели подходов к информатизации обучения будущих учителей для школ Международного бакалавриата.

Результаты. В ходе исследования установлено, что интеграция методических систем с использованием облачных технологий для организации совместной работы при подготовке будущих учителей для школ Международного бакалавриата способствует эффективности формирования профессиональной компетенции таких учителей.

Заключение. Экспериментально доказана эффективность разработанной модели подходов к интеграции методических систем дисциплин, составляющих основу подготовки будущих учителей для школ Международного бакалавриата.

Ключевые слова: информатизация образования, методическая система обучения, интеграция, облачные технологии, модель, подготовка педагогов, Международный бакалавриат

\section{Список литературы}

[1] Безукладников К.Э., Крузе Б.А. Лингводидактические основы подготовки учителя Международного бакалавриата: лингвоинформационный и компетентностный подходы // Вестник Пермского национального исследовательского политехнического университета. Проблемы языкознания и педагогики. 2013. № 7 (49). С. $42-50$.

[2] Никонорова Е.И. Применение инновационных ресурсов для индивидуализации обучения в системе «Международный бакалавриат» в условиях информатизации образования // Информатизация непрерывного образования - 2018. М.: РУДН, 2018. Т. 1. С. 639-645.

[3] Павлова A.E. Развитие коммуникативной компетенции координаторов программ «Международного бакалавриата» с использованием средств информатизации образования // Вестник Московского городского педагогического университета. Серия: Информатика и информатизация образования. 2019. № 4 (50). С. 59-63.

[4] Brown R. Mathematical Modelling in the International Baccalaureate, Teacher Beliefs and Technology Usage // Teaching Mathematics and its Applications: An International Journal of IMA. 2002. No. 21 (2). P. 67.

[5] Christodoulou A., Duncan J., Nelmes G. What is the effect of choice on students' motivation and performance? // IB Journal of Teaching Practice. 2012. Vol. 1. No 1. Pp. 1-15.

[6] Fostering interdisciplinary teaching and learning in the MYP / International Baccalaureate Organization. IB Publishing Ltd., 2009. 70 p.

[7] Grace P. Individuals \& Societies (MYP by concept 3). Hodder Education, 2017. 154 p.

[8] Grinshkun V., Usova N. Use of the Hardware and Software Complex "Moscow Electronic School" in Training Teachers Working Under the International Baccalaureate Programmes // Journal of Siberian Federal University. Humanities \& Social Sciences. 2019. Vol. 9. No. 12. Pp. 1622-1634.

[9] Hacking E.B., Blackmore C., Bullock K., Bunnell T., Donnelly M., Martin S. International Mindedness in Practice: The Evidence from International Baccalaureate Schools // Journal of Research in International Education. 2018. No. 17 (1). Pp. 3-16. 
[10] Halic O., Bergeron L., Kuvaeva A., Smith A. The International Baccalaureate's Bilingual Diploma: Global Trends, Pathways, and Predictors of Attainment // International Journal of Educational Research. 2015. Vol. 69. Pp. 59-70.

[11] Ryan A.M., Heineke A.J., Steindam C.E. Preparing Globally Minded Teachers Through the Incorporation of the International Baccalaureate // The Journal of Education. 2014. Vol. 194. No. 3. Pp. 39-51.

[12] Баженова С.А., Шунина Л.А. Возможности онлайн-сервисов для визуализации учебной информации // Информатизация непрерывного образования - 2018: материалы международной научной конференции. М.: РУДН, 2018. Т. 1. С. 413-416.

[13] Готская И.Б., Жучков В.М. Актуализация содержания обучения цифровым производственным технологиям бакалавров и магистров технологического образования: постановка проблемы // Информатизация непрерывного образования - 2018. М.: РУДН, 2018. Т. 1. С. 132-137.

[14] Заславская О.Ю. Компетенции учителя в области использования информационных и телекоммуникационных технологий в эпоху цифровой экономики // Информатизация непрерывного образования - 2018. М.: РУДН, 2018. Т. 1. С. 311-317.

[15] Кравиова А.Ю. Совершенствование системы подготовки будущих учителей в области информационных и коммуникационных технологий в условиях модернизации образования: дис. ... д-ра пед. наук. М., 2004. 267 с.

[16] Роберт И.В. О понятийном аппарате информатизации образования // Информатика и образование. 2002. № 12. С. 2-6.

\section{История статьи:}

Дата поступления в редакцию: 10 марта 2020 г.

Дата принятия к печати: 13 апреля 2020 г.

\section{Для цитирования:}

Grinshkun V.V., Shunina L.A. Cloud technologies as a basis for the integration of teacher training systems for the International Baccalaureate schools // Вестник Российского университета дружбы народов. Серия: Информатизация образования. 2020. Т. 17. № 3. C. 210-219. http://dx.doi.org/10.22363/2312-8631-2020-17-3-210-219

\section{Сведения об авторах:}

Гриншкун Вадим Валерьевич, член-корреспондент РАО, доктор педагогических наук, профессор, профессор кафедры информационных технологий в непрерывном образовании Российского университета дружбы народов. E-mail: vadim@grinshkun.ru

Шунина Любовь Андреевна, старший преподаватель кафедры информатизации образования Московского городского педагогического университета. E-mail: shunina. mgpu@gmail.com 